\title{
Espécies novas de Anthrenoides Ducke (Hymenoptera, Apidae, Andreninae) do Rio Grande do Sul e notas descritivas ${ }^{1}$
}

\author{
Danúncia Urban ${ }^{2}$
}

${ }^{1}$ Contribuição no 1716 do Departamento de Zoologia, Universidade Federal do Paraná.
${ }^{2}$ Departamento de Zoologia, Universidade Federal do Paraná, Caixa Postal 19020, 81531-980, Curitiba-PR, Brasil. Bolsista do CNPq.

\begin{abstract}
New species of Anthrenoides Ducke (Hymenoptera, Apidae, Andreninae) from Rio Grande do Sul and descriptive notes. Anthrenoides alineae sp. nov., A. birgitae sp. nov., A. elioi sp. nov., A. francisci sp. nov., A. gibbosus sp. nov., A. kelliae sp. nov., A. paulensis sp. nov., A. sidiae sp. nov. and A. sulinus sp. nov., as well as the females of $A$. magaliae Urban, 2005 and of A. reticulatus Urban, 2005 are described and illustrated. New data on geographical distribution of Anthrenoides and a key to the species from Rio Grande do Sul are also given.

KEYWORDS. Andrenidae; Neotropical; Protandrenini; taxonomy.

RESUMO. Espécies novas de Anthrenoides Ducke (Hymenoptera, Apidae, Andreninae) do Rio Grande do Sul e notas descritivas. Anthrenoides alineae sp. nov., A. birgitae sp. nov., A. elioi sp. nov., A. francisci sp. nov., A. gibbosus sp. nov., A. kelliae sp. nov., A. paulensis sp. nov., A. sidiae sp. nov. e A. sulinus sp. nov., assim como as fêmeas de $A$. magaliae Urban, 2005 e de A. reticulatus Urban, 2005 são descritas e ilustradas. São acrescentados novos dados sobre a distribuição geográfica de Anthrenoides e, também uma chave para a identificação das espécies do Rio Grande do Sul.
\end{abstract}

PALAVRAS CHAVE. Andrenidae; Neotropical; Protandrenini; taxonomia.

O estudo dos Anthrenoides Ducke, 1907, do Museu de Ciências e Tecnologia da PUCRS, levou à descrição das espécies apresentadas neste trabalho e à identificação de espécies coletadas no Rio Grande do Sul, dando continuidade ao conhecimento desse gênero de Protandrenini. A terminologia e as mensurações são as mesmas utilizadas nas descrições das abelhas, as medidas são dadas em milímetros. Nos comentários são apresentadas algumas comparações com as espécies descritas anteriormente (Schrottky, 1906; Urban, 1995, 2005 e 2007). O material-tipo das espécies novas está depositado na Coleção de Entomologia Pe. J. S. Moure, Departamento de Zoologia, UFPR, Curitiba (DZUP) e no Museu de Ciências e Tecnologia da PUCRS, Porto Alegre (MCTP).

\section{Anthrenoides alineae sp. nov.}

Figs. 1 e 11

Diagnose. Macho. Placa labral e clípeo amarelos; mácula parocular amarela reduzidíssima; clípeo e supraclipeal microreticulados, brilhantes; mesoscuto e escutelo microreticulados; sexto esterno com recorte mediano em "U" alargando para o ápice e o oitavo esterno com projeção mediana um pouco mais estreita que o diâmetro ocelo mediano.

Holótipo macho. Comprimento aproximado 5,12; comprimento da asa anterior 3,66; largura da cabeça 1,65; altura da cabeça 1,36; comprimento do olho 1,05. Tegumento predominante preto menos a placa labral, quase todo o clípeo e as nódoas paroculares amarelos, a placa labral com a ponta enegrecida, o clípeo com áreas látero-ventrais e duas nódoas pretas, estas próximas das fóveas tentoriais, a ponta do clípeo castanha; as máculas paroculares muito reduzidas e com o contorno irregular, localizadas junto aos ramos laterais da sutura epistomal, não chegando nem às órbitas nem às suturas subantenais externas; antenas com os artículos basais enegrecidos, o flagelo castanho dorsalmente e de cor amarelopalha no lado ventral do segundo flagelômero ao subapical; tégulas enegrecidas na metade basal e de um castanho translúcido no restante; asas tingidas de amarelo-acastanhado, pterostigma amarelo-âmbar e a veia R castanho-escura; tíbias anteriores e medianas com nódoa basal esbranquiçada; tergos com faixa marginal castanha e o bordo translúcido esbranquiçado, esternos castanho-claros.

Placa labral um pouco mais estreita na ponta, com cantos arredondados e carenas laterais até a base; clípeo sem carena mediana, com micro-reticulação brilhante e pontos esparsos, maiores que o dobro dos retículos; supraclipeal inteiramente micro-reticulada, sem área mediana lisa, com pontos esparsos e pouco conspícuos junto às suturas subantenais; fronte com carena mediana fina sulcada, o sulco muito fino e mais longo que o dobro do ocelo mediano; fóveas faciais curtas, medindo aproximadamente $1 / 5$ do comprimento do olho $(0,21: 1,05)$, foscas e com metade dorsal um pouco alargada lembrando uma gota estreita; genas sem angulosidade, mais estreitas no terço ventral; mesoscuto e escutelo micro-reticulados, com pontos quase iguais aos retículos e separados por intervalos variáveis de 2 a 5 diâmetros de ponto, no escutelo os pontos 
um pouco mais esparsos; mesepisternos micro-reticulados, com pontuação esparsa e fina pouco evidente; área basal do propódeo mais estreita que o metanoto, com rúgulas irregulares, algumas formando alvéolos estreitos e alongados; tergos com micro-reticulação superficial e brilhante, pontos rasos e esparsos no primeiro e mais densos, porém, rasos nos seguintes, faixa marginal dos tergos micro-reticulada e brilhante. Sexto esterno com as margens do recorte em "U" divergindo muito para a ponta, porém, com base mais larga que o diâmetro do ocelo mediano, carena basal pouco distinta da margem; projeção mediana do oitavo esterno um pouco mais estreita que o ocelo mediano e com ponta arredondada.

Pilosidade branca e alongada, não densa; colar pronotal com pêlos plumosos alongados, sem aparência aveludada; pêlos longos e esparsos intercalados com pêlos muito curtos no mesoscuto; nos tergos esparsa e curta, formando franjas laterais muito ralas do segundo ao quarto e franja completa também rala nos dois tergos seguintes, no distal os pêlos levemente amarelados.

Fêmea desconhecida.

Holótipo macho. BRASIL, Rio Grande do Sul. "Candiota / Chácara da HORTEC / 29.IX.1999 / Lopes, L. col"; " Oxalis / articulata / Savigny / Área 2 12:45”; “ LBP MCT / PUCRS / 38039” (DZUP).

Comentários. Pelo recorte mediano do sexto esterno com os bordos laterais divergindo para o ápice, A. alineae sp. nov. aproxima-se de $A$. micans Urban, 1995. Esta difere pelo recorte quase em forma de "V", muito estreito no meio e com a carena basal em semi-círculo; pelo mesoscuto e o escutelo polidos e denso-pontuados e os mesepisternos com pontuação grossa e bem marcada. As máculas amarelas das áreas paroculares de A. micans são grandes, quase quadrangulares, alcançando as órbitas e grande parte das suturas subantenais externas.

Espécie dedicada à Aline Cristina Martins.

\section{Anthrenoides birgitae sp. nov.}

\section{Fig. 7}

Diagnose. Fêmea. Fóveas faciais longas, largas e quase retangulares na metade dorsal e, muito estreitas ventralmente; clípeo brilhante com pontos grandes e micro-reticulação esparsa, área supraclipeal pontuada, tergo basal com pontos finíssimos muito esparsos.

Holótipo fêmea. Comprimento aproximado 8,03; comprimento da asa anterior 5,50; largura da cabeça 2,40; altura da cabeça 1,65; comprimento do olho 1,23. Cor predominante preta, antenas castanho-claras ventralmente a partir do terceiro flagelômero; tégulas enegrecidas no terço dorsal e no restante castanhas e translúcidas; asas fracamente tingidas de castanho, pterostigma castanho claro, um pouco amarelado, a veia $\mathrm{R}$ preta; pernas castanho-enegrecidas, sem nódoa amarela na base das tíbias, esporão mesotibial enegrecido; os tergos com faixa marginal castanha clara e os esternos castanhos com margem estreita esbranquiçada.

Placa labral quase quadrada com os cantos arredondados, as carenas laterais quase até a base e rúgulas basais concêntricas; clípeo brilhante com micro-reticulação fraca e pontos grandes, sem carena porém com uma linha mediana desprovida de pontos; supraclipeal brilhante com microreticulação junto ao clípeo e áreas micro-reticuladas esparsas, inteiramente pontuada, os pontos como os do clípeo; carena frontal fina, até o ocelo, mais estreita na metade dorsal; fóveas faciais mais longas que $1 / 3$ do comprimento do olho $(0,49$ : $1,23)$, com a metade dorsal quase retangular e ultrapassando o dobro da largura da ventral $(0,18: 0,08)$; mesoscuto polido e com micro-reticulação brilhante no terço basal, os pontos esparsos e de tamanho variável deixando grandes áreas lisas; escutelo polido e com pontos iguais aos do mesoscuto; mesepisternos micro-reticulados e foscos, com pontos muito finos na metade posterior; esporão mesotibial com o dente apical longo e fino, mais longo que o ocelo mediano, com 4 dentes longos subapicais (3 no esporão mesotibial esquerdo); depressão basal do propódeo um pouco mais longa que o metanoto, com algumas rúgulas basais; tergos microreticulados e um pouco brilhantes, o basal com pontos esparsos, os dois seguintes com pontos finos maiores que os retículos e menos esparsos.

Pilosidade branca e creme; curta e denso-plumosa no colar pronotal, alongada e denso-plumosa nos lobos pronotais; mesoscuto com pêlos curtos e longos muito esparsos; face ventral dos mesepisternos com cerdas dobradas na ponta; nos tergos muito curta e decumbente, pouco conspícua, com franjas de pêlos esparsos alongados nos lados do segundo e terceiro e franja quase completa no quarto tergo, quinto e sexto com pilosidade castanha longa.

Holótipo fêmea. BRASIL, Rio Grande do Sul. "São Francisco de / Paula, Pró-Mata, RS / Brasil 1-4-1997 / leg. Birgit Harter"; "15001 H: 228 / + 17608 + 238 / F: 86 11:30 símbolo de fêmea"; "Anthrenoides sp. g / símbolo de fêmea / B. Harter det. 1999" (DZUP).

Comentários. A fêmea de A. meloi Urban, 2005, também tem as fóveas faciais largas e quase retangulares na metade dorsal e muito estreitas ventralmente; entretanto, difere de $A$. birgitae sp. nov. por ter carena mediana no clípeo, placa labral lisa e o tergo basal denso-pontuado.

Espécie dedicada à Dra. Birgit Harter-Marques.

Macho desconhecido.

\section{Anthrenoides elioi sp. nov.}

Fig. 3

Diagnose. Macho. Placa labral preta, clípeo e paroculares inferiores amarelos, carena frontal fina e curta, máculas paroculares quase quadradas; mesoscuto polido, com microreticulação superficial em volta e pontos esparsos no disco, escutelo polido. Fêmea com clípeo e área supraclipeal polidos porém com áreas micro-reticuladas; tergo basal microreticulado brilhante, com pontos finos muito esparsos, sem áreas polidas laterais.

Holótipo macho. Comprimento aproximado 5,50; 


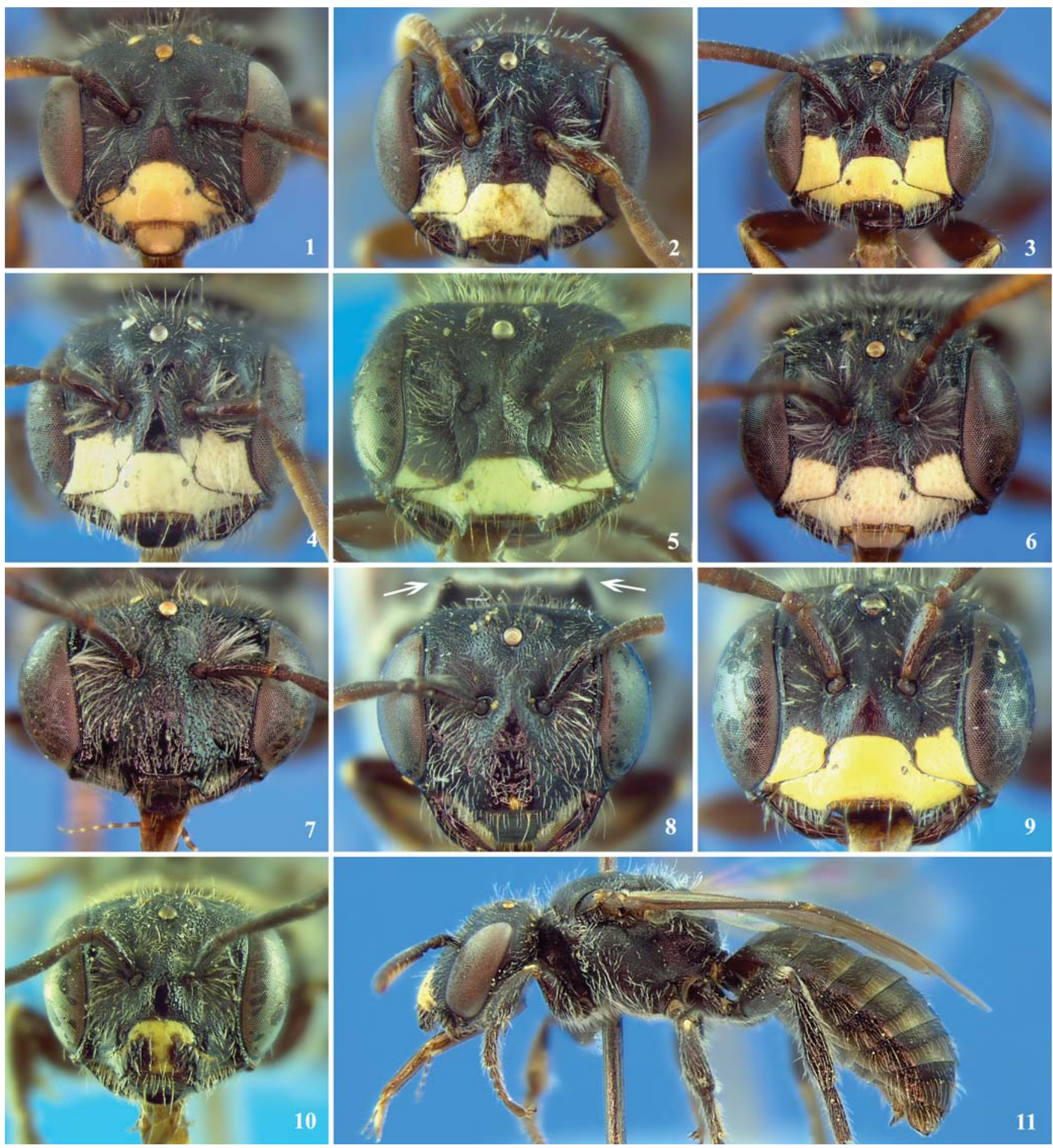

Figs. 1-11. 1-9, Espécies de Anthrenoides, vista frontal da cabeça: 1, A. alineae sp. nov.; 2, A. gibbosus sp. nov.; 3, A. elioi sp. nov.; 4, A. kelliae sp. nov.; 5, A. paulensis sp. nov.; 6, A. francisci sp. nov.; 7, A. birgitae sp. nov.; 8, A. sidiae sp. nov.; 9, A. sulinus sp. nov.; 10, cabeça da fêmea de A. magaliae; 11, Anthrenoides alineae sp. nov., em vista de perfil. Holótipos machos figs. 1 a 6,9 e 11, holótipos fêmeas figs. 7 e 8.

comprimento da asa anterior 4,15; largura da cabeça 1,84; altura da cabeça 1,25 ; comprimento do olho 1,08 . Tegumento preto predominando na cabeça e mesossoma. Cabeça com o clípeo e as paroculares inferiores amarelos, o clípeo com orla e duas manchas pequenas pretas perto das fóveas tentoriais; as máculas paroculares quadráticas, quase até o topo da sutura subantenal externa; antenas com os artículos basais pretos, castanhas na face dorsal a partir do terceiro flagelômero e castanho-claras na face ventral; tégulas tanslúcidas castanhoamareladas; asas tingidas levemente de castanho, as veias amarelo-acastanhadas e o pterostigma amarelo-âmbar; pernas castanhas, as tíbias anteriores com mácula amarela alongada 
na face anterior e as medianas com mácula amarela basal; metassoma castanho-avermelhado, tergos e esternos com a faixa marginal translúcida castanho-amarelada, passando a esbranquiçada e translúcida no bordo.

Placa labral quase retangular, com carenas laterais quase até a base e um pouco convergentes para a ponta; clípeo polido com pequenas áreas micro-reticuladas, sem carena mediana e com pontos grandes separados por espaços irregulares, alguns intervalos maiores que o diâmetro do ocelo mediano; supraclipeal polida com uma faixa fracamente microreticulada junto à sutura epistomal, sem pontos na área discal, um pouco elevada em direção à carena frontal e pontuada junto às suturas subantenais; carena frontal curta, ultrapassando um pouco os alvéolos e com um ponto alongado ventralmente; fóveas faciais estreitas, pouco mais longas que $1 / 4$ do comprimento do olho $(0,23: 1,08)$; genas um pouco angulosas ventralmente; mesoscuto polido com microreticulado fraquíssimo em algumas áreas, os pontos separados por intervalos irregulares deixando áreas lisas maiores que o ocelo mediano; escutelo polido com áreas grandes sem pontos; área basal do propódeo tão longa como o metanoto, com o contorno posterior elevado medialmente, micro-reticulada e com rúgulas muito fracas; mesepisternos micro-reticulados com pontos finos; tergos micro-reticulados, brilhantes e com faixa marginal fracamente lineolada, primeiro tergo com pontos muito finos esparsos e o segundo com pontos pequenos e rasos porém densos, sem áreas laterais polidas; sexto esterno com carena basal em arco, contínua com as margens laterais do recorte em "U", com base tão larga como seu comprimento e margens divergindo um pouco para os lados; ponta da projeção mediana do oitavo esterno quase uma vez e meia o diâmetro do ocelo mediano.

Pilosidade branca esparsa, curta e denso-plumosa no pronoto, formando faixas laterais de pêlos longos e esparsos nos tergos.

Fêmea. Comprimento aproximado 6,40; comprimento da asa anterior 5,0; largura da cabeça 2,16; altura da cabeça 1,63; comprimento do olho 1,22 . Tegumento preto, exceto a face ventral das antenas ocre-acastanhada a partir da ponta do primeiro flagelômero até o apical e o lado dorsal castanhoescuro; tégulas translúcidas castanhas; asas tingidas de castanho, pterostigma amarelo-âmbar; pernas castanhas, com nódoa amarelo-esbranquiçada na base das tíbias anteriores e medianas; esporão mesotibial âmbar esbranquiçado; tergos enegrecidos com faixa marginal translúcida castanha passando a esbranquiçada na ponta; esternos castanhos com margem fina translúcida esbranquiçada.

Placa labral retangular com rúgulas basais quase paralelas à articulação labro-clipeal e carenas laterais quase até a base; clípeo e supraclipeal polidos com área micro-reticulada nas proximidades do ramo transversal da sutura epistomal, clípeo sem carena mediana, com pontos grandes separados por espaços variando de duas a três vezes o diâmetro dos pontos; supraclipeal um pouco protuberante, com grande área discal polida, pontuada junto às suturas subantenais internas; carena frontal pouco elevada, com um ponto ventral e um sulco mediano muito fino, ultrapassando um pouco os alvéolos; fóveas faciais brilhantes e estreitas, medindo pouco mais de $1 / 4$ do comprimento do olho $(0,33: 1,22)$. Mesoscuto microreticulado, brilhante, com pontos distribuídos irregularmente deixando algumas áreas grandes sem pontos, denso-pontuado em volta; escutelo brilhante, com micro-reticulação rasíssima e espaços laterais grandes sem pontos; base do propódeo tão longa como o metanoto, micro-reticulada e com rúgulas finas irregulares, a margem posterior evidente; mesepisternos microreticulados e brilhantes com pontos muito esparsos e rasos; esporão mesotibial fino, com 5 dentes curtos na metade distal; tergos micro-reticulados, não foscos, o primeiro com pontos finos esparsos e o segundo com pontos também finos porém densos dorsalmente, faixa marginal micro-reticulada e um pouco brilhante.

Pilosidade branca, inclusive na face dorsal das tíbias posteriores, porém aí as cerdas um pouco enegrecidas na base; muito curta e denso-plumosa no colar pronotal, denso-plumosa e um pouco mais longa nos lobos pronotais; face ventral dos mesepisternos com cerdas curtas, com a ponta dobrada para trás; nos tergos decumbente e muito curta.

Holótipo macho. BRASIL, Rio Grande do Sul. "Candiota - RS / Chácara da HORTEC / 27.X.1999 / Lunardi, M. col"; "Oxalis articulata /Savigny / Área 8 Hora 11:07”; “LBPMCT / PUCRS / 37160” (DZUP). Parátipos com os mesmos dados de procedência do holótipo: um macho e 4 fêmeas (DZUP); 27.X.1999, Lunardi, M., 5 machos e 4 fêmeas (MCTP); 22.X.1999, 4 fêmeas e 1 macho (MCTP); Souza, L., 22.X.1999, 3 fêmeas (MCTP).

Comentários e variações. Na chave de Urban (2005) o macho chega em A. meridionalis (Schrottky, 1906), que tem a área supraclipeal abaulada, a fronte protuberante e sem carena mediana, o tergo basal polido, sem micro-reticulação e áreas subapicais polidas no segundo tergo. Na chave citada acima, a fêmea chega em A. politus Urban, 2005, pela carena frontal curta e pelas cerdas quase inteiramente brancas na face dorsal das tíbias posteriores. Anthrenoides politus tem pontuação densa nos dois tergos basais, clípeo polido e o esporão mesotibial com 4 a 5 dentes mais longos que o diâmetro do esporão. Dos 8 parátipos fêmeas coletados em 27.X.1999, 4 têm as paroculares inferiores inteiramente pretas, as demais têm nódoas amarelas junto ao clípeo, variando de pouco conspícuas até mais largas que o diâmetro do ocelo mediano e arqueadas.

Espécie dedicada ao Dr. Elio Corseuil.

\section{Anthrenoides francisci $\mathbf{s p . ~ n o v . ~}$}

Fig. 6

Diagnose. Macho. Placa labral, clípeo e paroculares inferiores esbranquiçados; área supraclipeal, mesoscuto e escutelo micro-reticulados; base do propódeo com o contorno posterior um pouco elevado, com rúgulas formando alvéolos longos e irregulares medianamente. Fêmea com clípeo e supraclipeal micro-reticulados e brilhantes; clípeo sem carena 
mediana, com pontos rasos grandes, também microreticulados; placa labral com rúgulas basais divergentes partindo de uma rúgula mediana, larga e baixa junto ao clípeo porém fina e irregular no meio da placa.

Holótipo macho. Comprimento aproximado 7,49; comprimento da asa anterior 5,18; largura da cabeça 2,30; altura da cabeça 1,80; comprimento do olho 1,29 . Tegumento predominantemente preto; cabeça com a placa labral, o clípeo e as paroculares inferiores esbranquiçados, o clípeo com a margem castanha e duas nódoas pretas próximas das fóveas tentoriais, as máculas paroculares em forma de gota, até a ponta ventral das suturas subantenais externas; antenas enegrecidas com a face ventral amarelo-palha do ápice do segundo flagelômero até o distal; tégulas castanho-escuras, translúcidas; asas fracamente tingidas de castanho, pterostigma castanho; pernas castanho-enegrecidas, tíbias anteriores e medianas sem nódoa basal amarela; os basitarsos um pouco mais claros e os demais tarsômeros amarelo-âmbar. Tergos castanho-enegrecidos com faixa marginal castanha amarelada, o primeiro com uma área ferrugínea no disco, os dois seguintes levemente tingidos de ferrugíneo, o tergo distal amarelo-âmbar com áreas acastanhadas. Esternos castanhoescuros com margem amarelada.

Placa labral trapezoidal, curta e sem rúgulas, carenas laterais na metade distal; clípeo sem carena mediana, com microreticulação fraca e pontos grandes; supraclipeal microreticulada e fosca, com pontuação densa junto às suturas subantenais internas porém sem pontos no disco; fronte com carena até o ocelo mediano, muito fina e mais elevada na área interalveolar; fóveas faciais elipsóides, mais curtas que 1/4 do comprimento do olho $(0,27: 1,29)$; genas com angulosidade ventral; mesoscuto e escutelo micro-reticulados, no mesoscuto os pontos um pouco maiores que os retículos e separados por intervalos de 3 a 5 diâmetros de ponto, escutelo com pontos maiores, medindo aproximadamente o dobro do tamanho dos mesoscutais; mesepisternos micro-reticulados; depressão basal do propódeo tão longa como o metanoto, com rúgulas formando alvéolos longos e irregulares no meio e muito curtos nos flancos, o contorno posterior um pouco elevado; tergos micro-reticulados com margem lineolada, o primeiro com pontos finos muito esparsos; sexto esterno com carena basal reta, contínua com as margens laterais do recorte em "U"; ponta da projeção mediana do oitavo esterno estreita, quase igualando o diâmetro do ocelo mediano.

Pilosidade branca predominando; alongada e sem aspecto aveludado no pronoto; cabeça, mesoscuto e escutelo com pêlos ramificados finos e longos, mais esparsos no escutelo; curta e esparsa nos tergos, decumbente, porém um pouco alongada dos lados formando franjas ralas; no quinto e sexto tergos pêlos longos esparsos formando franja completa; tergo distal com pêlos de cor creme.

Fêmea. Comprimento aproximado 8,11 ; comprimento da asa anterior 5,07; largura da cabeça 2,35; altura da cabeça 1,86; comprimento do olho 1,36. Tegumento predominante enegrecido, as antenas amarelo-palha ventralmente, a partir da ponta do terceiro flagelômero; tégulas translúcidas castanho-amareladas; asas tingidas de amarelo-acastanhado, pterostigma amarelo-pálido; pernas castanhas, sem nódoa basal amarela nas tíbias anteriores e medianas, com os tarsômeros medianos e distais amarelo-âmbar e os basitarsos castanhos; esporão mesotibial castanho-enegrecido; tergos castanho-escuros com larga faixa marginal castanhoamarelada, mais pálida na ponta, o primeiro com grande área discal ferrugíneo-escura; esternos castanho-escuros com a faixa marginal como nos tergos.

Placa labral trapezoidal, mais curta que sua largura na ponta e com margens retas junto ao clípeo, com rúgulas basais divergentes partindo de uma rúgula mediana larga e baixa junto ao clípeo porém fina e irregular no meio da placa, carenas laterais nos $2 / 3$ distais; clípeo e supraclipeal micro-reticulados e brilhantes, clípeo sem carena mediana e com pontos grandes e rasos, também micro-reticulados, supraclipeal com pontos como os do clípeo aos lados; carena frontal fina e lisa, entre os alvéolos; fóveas faciais longas e com alargamento sub-dorsal, pouco mais longas que $1 / 3$ do comprimento do olho $(0,55$ : 1,36); esporão mesotibial com 4 dentes grossos; mesoscuto, escutelo, área basal do propódeo e tergos basais como no macho.

Pilosidade branca predominando; no pronoto como no macho; alongada e ereta no mesoscuto; face ventral dos mesepisternos com as cerdas dobradas em gancho na ponta; pouco conspícua nos tergos basais, castanho-pálida nos dois tergos distais. Face dorsal das tíbias posteriores com cerdas bicoloridas, enegrecidas na base e brancas no restante.

Holótipo macho. BRASIL, Rio Grande do Sul. "São Francisco de / Paula Pró-Mata, RS, / Brasil 15-II-1997 / leg. Birgit Harter"; "15220 H: 227 / F: 86 9-9:30"; "Anthrenoides sp. b / símbolo de macho / B. Harter det. 1999" (DZUP). Parátipos com a mesma procedência do holótipo: 11-II-1996, leg. Birgit Harter; 1 fêmea (DZUP) e 1 macho (MCTP).

Comentários. O macho desta espécie, na chave de Urban (2005), chega em A. elegantulus Urban, 2005, pelo colorido das máculas cefálicas. Anthrenoides elegantulus difere por ter o clípeo e o disco da área supraclipeal polidos, mesoscuto e escutelo polidos com pontos muito esparsos e a depressão basal do propódeo polida e sem rúgulas. A fêmea de $A$. francisci sp. nov. chega em A. ornatus Urban, 2005, na chave citada acima, que também tem a placa labral com rúgulas divergentes para os lados; porém difere pela depressão basal do propódeo micro-reticulada e sem rúgulas ou com rúgulas finas esparsas e pelo tergo basal com micro-reticulação muito superficial e áreas laterais polidas.

Nome da espécie relativo à localidade-tipo.

\section{Anthrenoides gibbosus sp. nov.}

Fig. 2

Diagnose. Macho. Protuberâncias gibosas nas áreas paroculares superiores, incluindo as fóveas faciais; área ocelar 
protuberante e arredondada, um pouco deprimida junto ao ocelo mediano; máculas cefálicas esbranquiçadas e as áreas subantenais inteiramente pretas.

Holótipo macho. Comprimento aproximado 5,63; comprimento da asa anterior 4,26; largura da cabeça 1,77; altura da cabeça 1,31; comprimento do olho 0,97 . Tegumento predominante preto, com a placa labral castanho-enegrecida e as seguintes áreas esbranquiçadas na cabeça: o clípeo, com a margem enegrecida e sem nódoas pretas junto às fóveas tentoriais; máculas nas paroculares inferiores, não chegando aos alvéolos antenais e com o contorno dorsal em linha inclinada das suturas subantenais até a base das mandíbulas. Antenas castanho-pálidas em toda a face dorsal, e de um amarelo-palha ventralmente a partir do terceiro flagelômero, os dois basais com pequena área amarelo-palha. Tégulas amarelo-acastanhadas; asas tingidas de castanho-amarelado, pterostigma amarelado, veia R castanha; pernas amarelo-âmbar com nódoa esbranquiçada na base das tíbias anteriores e medianas e, as posteriores com a placa basitibal amarela orlada com preto; tarsômeros intermediários e distais de um amarelo pálido. Tergos basais e apicais âmbar com áreas enegrecidas, o terceiro e o quarto tergos castanho-enegrecidos com nódoas irregulares de cor âmbar; a faixa marginal translúcida ligeiramente amarelada; esternos âmbar com áreas castanhas.

Placa labral quase retangular, arredondada na ponta e sem rúgulas, com carenas laterais quase até a base; clípeo com pontos grandes esparsos, em grande parte polido, com área micro-reticulada brilhante nas proximidades do ramo transversal da sutura epistomal; supraclipeal micro-reticulada e sem pontos no disco, elevada dorsalmente; sem carena frontal porém com elevação mediana marcada por um sulco fino partindo de uma fóvea ventral estreita e longa até uma depressão mais larga que a fóvea ventral, próxima da área ocelar, a partir daí com um sulco finíssimo quase até o ocelo mediano; paroculares superiores com protuberâncias gibosas incluindo as fóveas faciais; área ocelar protuberante e arredondada, um pouco deprimida junto ao ocelo mediano; fóveas faciais estreitas, brilhantes e curtas, medindo aproximadamente $1 / 4$ do comprimento do olho $(0,25: 0,97)$; genas sem angulosidade, mais estreitas no terço ventral. Mesoscuto com micro-reticulação fraca, denso-pontuado no terço basal e junto ao escutelo, no restante com pontos esparsos deixando espaços lisos grandes e áreas polidas discais; escutelo micro-reticulado, com os pontos muito esparsos e distintamente maiores que os do mesoscuto; área basal do propódeo quase tão longa como o metanoto com rúgulas anastomosadas e o contorno posterior bem marcado; mesepisternos micro-reticulados com pontos finos muito esparsos; sexto esterno com os bordos laterais do recorte em "U" contínuos com a carena basal em arco e com uma pequena angulosidade mediana, prolongada em carena para a base do esterno; oitavo esterno com a ponta igualando o dobro do diâmetro do ocelo mediano.

Pilosidade branca, denso-plumosa e curta no pronoto, no mesoscuto com pêlos longos e curtos; esparsa nos tergos, franja pré-marginal decumbente muito esparsa no quarto e quinto tergos.

Holótipo macho. BRASIL, Rio Grande do Sul. "Caçapava do / Sul RS / Guaritas / Brasil 26.5.1991 / C. Schlindwein leg. "; "5004: H: 288 / F: 40"; "Anthrenoides / meridionalis [símbolo de macho] / (Schrottky, 1906) / Moure det. 1992 “; "MCT / PUCRS” (DZUP).

Comentário. Esta espécie tem em comum com A. kelliae sp. nov., protuberâncias paroculares e ocelar, entretanto $A$. kelliae sp. nov. difere pelas áreas subantenais com mácula esbranquiçada e, pelo clípeo, área supraclipeal e escutelo polidos.

Nome alusivo às protuberâncias dorsais da face.

Fêmea desconhecida.

\section{Anthrenoides kelliae sp. nov.}

Fig. 4

Diagnose. Macho e fêmea. Protuberâncias gibosas nas áreas paroculares superiores, incluindo as fóveas faciais; área ocelar protuberante e arredondada, um pouco deprimida junto ao ocelo mediano. Macho com máculas cefálicas esbranquiçadas inclusive nas áreas subantenais.

Holótipo macho. Comprimento aproximado 6,0; comprimento da asa anterior 4,52; largura da cabeça 1,83; altura da cabeça 1,44; comprimento do olho 0,98 . Tegumento preto, exceto o clípeo e as máculas paroculares esbranquiçados, o clípeo com duas pequenas nódoas pretas na altura das fóveas tentoriais e a margem também preta; as máculas paroculares quadráticas, quase até a altura dos alvéolos antenais e com o limite dorsal levemente côncavo; máculas na metade ventral das áreas subantenais. Antenas pretas dorsalmente e, do segundo flagelômero ao distal amarelo-acastanhada ventralmente. Tégulas castanhas; asas tingidas de castanho levemente amarelado, pterostigma amarelo-acastanhado, veia $\mathrm{R}$ castanho-enegrecida; pernas pretas, com nódoa esbranquiçada na base das tíbias anteriores e medianas; tarsos castanhos. Tergos castanhos com orla translúcida castanhoamarelada nos dois basais e nos apicais, castanha nos intermediários; o tergo distal amarelo-âmbar; esternos castanhos com a margem amarelo-esbranquiçada translúcida, mais larga no meio.

Placa labral quase retangular, arredondada na ponta, sem rúgulas e com carenas laterais até o meio; clípeo polido com pontos grandes esparsos; supraclipeal polida e elevada, sem pontos no disco; fronte polida medialmente, sem carena porém elevada e com um sulco finíssimo entre um ponto ventral pequeno e uma fóvea alongada ladeada por carenas baixas contínuas com a área ocelar; paroculares superiores com protuberâncias gibosas incluindo as fóveas faciais; área ocelar protuberante e arredondada, um pouco deprimida junto ao ocelo mediano; as fóveas faciais elipsóides e curtas, um pouco mais largas no meio, medindo aproximadamente $1 / 4$ do comprimento do olho $(0,23: 0,98)$; genas sem angulosidade ventral, estreitando gradualmente no terço ventral; mesoscuto 
polido porém denso-pontuado, os pontos quase igualando os intervalos entre os mesmos; escutelo polido e com pontos um pouco maiores que os mesoscutais e muito esparsos; área basal do propódeo quase tão longa como o metanoto, com micro-reticulação brilhante e rúgulas esparsas; mesepisternos micro-reticulados com pontos muito finos esparsos; tergos brilhantes com micro-reticulação superficial e faixa marginal larga brilhante e lineolada, tergo basal com pontos finos muito esparsos no disco; sexto esterno com carena basal em arco, contínua com os bordos laterais do recorte em "U"; projeção mediana do oitavo esterno tão larga na ponta como o dobro do diâmetro do ocelo mediano.

Pilosidade branca; denso-plumosa e curta no pronoto, curta e densa no mesoscuto, com pêlos longos esparsos de permeio; franja pré-marginal decumbente muito esparsa no quarto e quinto tergos.

Fêmea. Comprimento aproximado 5,58; comprimento da asa anterior 4,27; largura da cabeça 1,92; altura da cabeça 1,45; comprimento do olho 0,98. Cor predominante enegrecida. Antenas amarelo-palha na face ventral a partir do quarto flagelômero até o distal; base das tíbias anteriores e medianas com nódoa amarelo-pálida muito pequena; tégulas enegrecidas; asas como no macho; esporão mesotibial amareloâmbar. Tergos com faixa marginal larga amarelada, nos esternos a faixa marginal estreita e esbranquiçada.

Placa labral retangular com carenas laterais quase até a base e rúgulas basais finas divergentes para os lados; clípeo e supraclipeal polidos, clípeo com pontos distribuídos regularmente; supraclipeal brilhante e polida, com pontos somente junto às suturas subantenais internas; fronte e áreas faciais como no macho; fóveas faciais elipsóides, um pouco mais largas dorsalmente, medindo quase $1 / 3$ do comprimento do olho $(0,34: 0,98)$; mesoscuto, escutelo, base do propódeo, mesepisternos e tergos como no macho; esporão mesotibial com 3 dentes subapicais finos.

Pilosidade branca; pêlos do pronoto como no macho; no mesoscuto muito curta, intercalada com cerdas finas eretas e longas; área ventral dos mesepisternos com cerdas curtas com a ponta dobrada para trás; escassa nos tergos, formando franjas laterais no terceiro e quarto, quinto e sexto tergos com os pêlos acastanhados.

Holótipo macho. BRASIL, Rio Grande do Sul. " Candiota, RS / Chácara da HORTEC / 08.IV.1999 / Lopes, L. col.”; " Oxalis articulata / Savingy / Área 1 Hora: 12:10”; " LBP MCT PUCRS / 37334” (DZUP). Parátipos com a mesma procedência do holótipo: 10:20, 37241, 1 macho (MCTP); 12:13, 37492, 1 fêmea (DZUP).

Comentários. O holótipo com a pilosidade do mesoscuto danificada por substância resinosa. O parátipo macho tem as máculas subantenais esbranquiçadas menores do que as do holótipo, pilosidade mesoscutal branca e o sulco frontal mais evidente. As protuberâncias paroculares e a ocelar como em A. gibbosus sp. nov., que difere pelas áreas subantenais inteiramente pretas e micro-reticulação na área supraclipeal e no escutelo.
Espécie dedicada à M. Sc. Kelli dos Santos Ramos.

\section{Anthrenoides paulensis sp. nov.}

Fig. 5

Diagnose. Macho. Placa labral preta, máculas cefálicas esbranquiçadas, clípeo micro-reticulado; genas angulosas ventralmente; depressão basal do propódeo micro-reticulada, sem rúgulas; segmentos basais do metassoma castanhoavermelhados; palpômero basal do lábio um pouco mais curto que a soma dos 3 distais.

Holótipo macho. Comprimento aproximado 7,48; comprimento da asa anterior 5,61; largura da cabeça 2,20; altura da cabeça 1,61; comprimento do olho 1,24. Tegumento predominante castanho-enegrecido, exceto o clípeo e as nódoas paroculares junto ao clípeo, esbranquiçados; o clípeo com duas nódoas arredondadas castanho-enegrecidas próximas das fóveas tentoriais, a margem castanho-enegrecida no meio e preta nos lados, com mancha enegrecida irregular estreita junto ao ramo transversal da sutura epistomal; as nódoas paroculares até os flancos da sutura epistomal, muito estreitas medialmente e um pouco mais largas perto das órbitas, aí tão largas como o diâmetro do ocelo mediano; antenas enegrecidas porém com a face ventral castanha, do terceiro flagelômero ao distal. Mesossoma enegrecido com áreas castanho-avermelhadas. Tégulas castanhas, as asas tingidas de amarelo-méleo, mais fortemente nas veias, pterostigma amarelo pálido; pernas castanhas com a face externa das tíbias castanho-enegrecidas; tíbias anteriores e medianas sem nódoa basal amarela, placa basitibial amarelo-âmbar no disco; esporão mesotibial castanho. Tergos basais castanho-avermelhados, o terceiro tergo com área discal enegrecida e os demais castanho-enegrecidos, com faixa marginal translúcida castanho-amarelada; esternos castanho-avermelhados com mescla de enegrecido e faixa marginal translúcida amarelada.

Placa labral trapezoidal; clípeo micro-reticulado com pontos finos esparsos; supraclipeal micro-reticulada, sem pontos, quase fosca e um pouco elevada em direção à carena frontal; fronte com carena fina até meia distância dos alvéolos ao ocelo mediano; fóveas faciais brilhantes, medindo menos que $1 / 4$ do comprimento do olho $(0,28: 1,24)$; genas prolongadas para trás em ângulo reto e com um pequeno tubérculo ventral. Mesoscuto com micro-reticulação brilhante e superficial, a pontuação irregular, os pontos separados por intervalos de 23 diâmetros de ponto; escutelo polido com áreas microreticuladas e os pontos maiores e mais esparsos que os mesoscutais; mesepisternos micro-reticulados com pontos esparsos; depressão basal do propódeo mais longa que o metanoto, inteiramente micro-reticulada e brilhante, sem rúgulas e com o contorno posterior pouco marcado. Tergos micro-reticulados, brilhantes com a faixa marginal também brilhante porém fracamente lineolada; o primeiro tergo quase sem pontos, os dois seguintes com pontos esparsos. Sexto esterno com o recorte em "U" quase tão longo como o dobro da largura mínima, fracamente alargado junto à base, os ramos 
laterais do recorte prolongados basalmente em carena arqueada; ponta da projeção mediana do oitavo esterno arredondada e quase tão larga como o diâmetro do ocelo mediano.

Pilosidade branca predominando, inclusive no clípeo; alongada no pronoto, tanto no colar como nos lobos, sem aspecto aveludado; no mesoscuto com mescla de pêlos curtos e longos; face ventral dos basitarsos com cerdas amareloacastanhadas.

Holótipo macho. BRASIL, Rio Grande do Sul. "Pró-Mata / S. Francisco de / Paula, RS / 21.12.1996 / C. Leistikow leg. 21.12.96"; "Anthrenoides spec. 3"; "21.12 [n 84 e símbolo de macho]"; "770 / MCP" (DZUP). Parátipo macho da mesma localidade do holótipo: 18.12.1996, Birgit Harter leg. (DZUP).

Comentários. A placa labral está parcialmente encoberta pelas mandíbulas no holótipo, porém no parátipo está exposta, é trapezoidal com a ponta bi-angulosa e as carenas laterais pouco evidentes na metade distal; o parátipo tem as genas angulosas ventralmente mas sem tubérculo. Esta espécie tem em comum com A. lavrensis Urban, 2007, conhecida de Minas Gerais, os seguintes caracteres: placa labral enegrecida, máculas cefálicas esbranquiçadas, o clípeo e a área supraclipeal microreticulados. Entretanto, A. lavrensis tem o primeiro palpômero labial longo, medindo aproximadamente uma vez e meia a soma dos 3 distais; o clípeo enegrecido na parte dorsal; rúgulas curtas na área basal do propódeo; o sexto esterno com o recorte em "U" alargado junto à base e os bordos divergindo para a ponta. Em A. paulensis o primeiro palpômero labial é mais curto que a soma dos 3 distais; o clípeo tem uma estria preta muito fina junto à sutura epistomal; a base do propódeo é desprovida de rúgulas e o recorte em "U" do sexto esterno é estreito e longo, com as margens paralelas em grande parte.

Etimologia. Nome relativo à localidade-tipo.

Fêmea desconhecida.

\section{Anthrenoides sidiae sp. nov.}

Fig. 8

Diagnose. Fêmea. Projeções látero-dorsais angulosas no pronoto, mais longas que o diâmetro do ocelo mediano e voltadas para cima; clípeo polido porém com micro-reticulação pouco marcada junto ao ramo transversal da sutura epistomal; supraclipeal polida e quase sem pontos no disco.

Holótipo fêmea. Comprimento aproximado 6,22; comprimento da asa anterior 4,88; largura da cabeça 2,21; altura da cabeça 1,73; comprimento do olho 1,25. Tegumento preto exceto uma nódoa clípeal amarela médio-apical; face ventral do flagelo amarelo-acastanhada a partir da ponta do terceiro flagelômero até o subapical, o distal castanho; tégulas enegrecidas na metade anterior e amarelo-acastanhadas e translúcidas na posterior; asas tingidas de castanho claro, veias castanhas menos a $\mathrm{R}$ enegrecida; pterostigma amareloacastanhado; pernas anteriores e medianas com nódoa basal amarelo-esbranquiçada, esporão mesotibial amarelo-âmbar; tergos com faixa marginal translúcida acastanhada, quase transparente na ponta; esternos com faixa marginal estreita translúcida um pouco acastanhada.

Placa labral quase retangular, sem rúgulas, com cantos arredondados e carenas laterais até a base; clípeo polido porém fracamente micro-reticulado junto ao ramo transversal da sutura epistomal, com pontos maiores na metade distal, separados por espaços variáveis; supraclipeal brilhante e micro-reticulada com área discal polida e quase sem pontos, nos lados com micro-reticulação brilhante e pontuação densa; fronte sem carena mediana, um pouco elevada e com um sulco muito fino entre os alvéolos, partindo de um ponto ventral; fóveas faciais foscas, arredondadas ventralmente e um pouco afiladas na ponta dorsal, medindo pouco mais de $1 / 4$ do comprimento do olho $(0,34: 1,25)$; pronoto com duas projeções látero-dorsais angulosas, voltadas para cima, com a face anterior plana e contínua com o restante do pronoto e, a posterior alargando em direção ao mesoscuto, as projeções afastadas por uma distância igual ao dobro do espaço entre os ocelos laterais e os olhos (0,38: 0,76); mesoscuto brilhante, com micro-reticulação muito fraca e pontuação mais densa em volta, os pontos separados por espaços irregulares no disco, deixando grandes áreas lisas; escutelo polido com pequenas áreas micro-reticuladas, os pontos como os do mesoscuto; área basal do propódeo tão longa como a metade do comprimento do metanoto, com o contorno posterior bem marcado medianamente e rúgulas curtas irregulares; mesepisternos micro-reticulados com pontos como os do mesoscuto porém muito rasos; esporão mesotibial com 3 espinhos subapicais finos, pouco maiores que os basais; tergos micro-reticulados, brilhantes, com faixa marginal microreticulada, a pontuação densa no segundo e terceiro tergos, no basal menos densa.

Pilosidade branca, menos na face ventral dos basitarsos, amarelo-âmbar, nos basitarsos anteriores inteiramente dessa cor; cerdas brancas na face externa das tíbias posteriores; os pêlos muito curtos e denso-plumosos no colar e nos lobos pronotais, esparsos e muito curtos no dorso do mesossoma e nos tergos.

Holótipo fêmea. BRASIL, Rio Grande do Sul. "Viamão - RS / 23.IX.1985 / B. Blochtein leg.; "Col. MCN / 93.011”; "Fundação/ Zoobotânica do RS" (DZUP).

Comentários. Espécie facilmente reconhecida pelas projeções angulosas látero-dorsais do pronoto; primeiro palpômero labial tão longo como a soma dos três distais e as gáleas curtas, com a metade do comprimento dos olhos. $\mathrm{O}$ espécime está estilopizado.

Em homenagem à Dra. Sídia Witter Freitas, da Fundação Estadual de Pesquisa Agropecuária, RS.

Macho desconhecido.

\section{Anthrenoides sulinus sp. nov.} Fig. 9

Diagnose. Macho. Fronte e paroculares superiores quase foscas, com pontos rasos pouco maiores que os retículos; máculas cefálicas amarelas e a placa labral enegrecida; projeção 
mediana do oitavo esterno larga subapicalmente porém com a ponta muito fina; fóveas faciais muito curtas; clípeo polido com micro-reticulação esparsa em uma pequena área dorsal; supraclipeal micro-reticulada, brilhante, com área discal polida. Fêmea. Fronte e paroculares superiores como no macho; mesoscuto e escutelo micro-reticulados com pontos muito rasos e finos; tergos micro-reticulados, o primeiro com pontos finos esparsos.

Holótipo macho. Comprimento aproximado 7,64; comprimento da asa anterior 5,68; largura da cabeça 2,06; altura da cabeça 1,60; comprimento do olho 1,20. Cabeça enegrecida, menos o clípeo e as máculas paroculares amarelos; clípeo com a margem e duas nódoas arredondadas enegrecidas próximas das fóveas tentoriais e mácula das paroculares em forma de gota, com a margem dorsal ondulada; antenas enegrecidas com os flagelômeros castanho-claros ventralmente, da ponta do terceiro até o distal. Mesossoma castanho enegrecido, com uma tonalidade mais clara no propódeo; tégulas enegrecidas na metade basal e castanho-amareladas na metade distal; asas tingidas de amarelo-âmbar, pterostigma amarelo-âmbar; pernas castanho-escuras com nódoa amarela pequena na base das tíbias anteriores e medianas, placa basitibial castanhoamarelada; basitarsos enegrecidos e os demais tarsômeros amarelo-claros. Tergos enegrecidos com larga margem translúcida amarelada, os dois basais com larga área discal castanho-avermelhada.

Placa labral retangular com cantos arredondados e carenas laterais quase até a base; clípeo polido com micro-reticulação esparsa junto à sutura epistomal; supraclipeal micro-reticulada e brilhante, protuberante, com área polida e quase sem pontos no disco; carena frontal curta e baixa; fóveas faciais elipsóides, muito reduzidas, medindo aproximadamente $1 / 6$ do comprimento do olho $(0,19: 1,20)$; genas com angulosidade ventral obtusa, sem tubérculo; mesoscuto micro-reticulado e brilhante, com pontos pequenos rasos, pouco maiores que os retículos e separados por distância variável de 2 a 5 diâmetros de ponto, a micro-reticulação muito fraca no disco; escutelo com micro-reticulação pouco marcada em áreas esparsas, entremeadas com áreas polidas, com pontos um pouco maiores que os mesoscutais e também pontos muito pequenos; mesepisternos micro-reticulados com pontos rasos esparsos; depressão basal do propódeo mais longa que o metanoto, micro-reticulada; tergos basais brilhantes com micro-reticulação irregular, o primeiro com pontos finos muito esparsos, os dois seguintes com pontos um pouco maiores e rasos, esparsos, a faixa marginal com micro-reticulação muito superficial; sexto esterno com o recorte em "U" quase tão largo como longo, com uma depressão médio-basal junto ao recorte, contornada por uma área inflada em arco, os ramos laterais do recorte em "U" não prolongados em carena basal; projeção mediana do oitavo esterno larga subapicalmente, quase igualando o dobro do diâmetro do ocelo mediano, porém afinando muito para a ponta.

Pilosidade branca em grande parte; curta e denso-plumosa no pronoto, mais alongada nos lobos; curta no mesoscuto, com pêlos longos esparsos; quinto e sexto tergos com franja decumbente rala, o distal com pêlos levemente acastanhados; segundo ao quinto esterno com pilosidade curta e decumbente até a margem.

Fêmea. Comprimento aproximado 8,42; comprimento da asa anterior 6,07; largura da cabeça 2,40; altura da cabeça 1,87; comprimento do olho 1,44. Tegumento castanho-enegrecido; antenas castanho-escuras ventralmente a partir do quinto flagelômero; asas tingidas de castanho, pterostigma amareloâmbar; pernas castanho-enegrecidas com nódoa amarela muito pequena na base das tíbias anteriores e medianas; esporões mesotibiais castanhos; tergos com faixa marginal translúcida levemente amarelada e os esternos com a margem esbranquiçada.

Placa labral retangular com rúgulas basais irregulares e carenas laterais quase até a base; clípeo com pontos grandes, polido na metade ventral e com micro-reticulação brilhante na metade dorsal, os pontos também micro-reticulados; supraclipeal com área discal elevada, polida e quase sem pontos, micro-reticulada nos flancos e junto à sutura epistomal; carena frontal curta, na área interalveolar, com sulco finíssimo partindo de um ponto maior que os adjacentes; fóveas faciais curtas, medindo menos de $1 / 4$ do comprimento do olho $(0,31$ : $1,44)$; mesoscuto e escutelo micro-reticulados, quase foscos, com pontos muito rasos e pouco maiores que os retículos, separados por espaços variando de 3-5 diâmetros de ponto; mesepisternos micro-reticulados; esporões mesotibiais com 5 a 6 dentes na metade distal; depressão basal do propódeo tão longa como o metanoto, com o rebordo posterior pouco marcado, micro-reticulada e com rúgulas irregulares finíssimas; tergos basais com micro-reticulação irregular, o primeiro com pontos finos muito esparsos, os dois seguintes com pontos rasos pouco maiores e menos esparsos, faixa marginal com micro-reticulação e sem pontos.

Pilosidade branca predominando, creme-amarelada no lado ventral dos tarsos, castanho-clara nos dois tergos distais; o pronoto como no macho; pêlos muito curtos e decumbentes no mesoscuto, intercalados com pêlos longos; tíbias posteriores com cerdas quase inteiramente brancas, passando a acastanhadas na área basal; mesepisternos com cerdas de ápice dobrado em gancho; lados dos tergos intermediários com pêlos longos e esparsos.

Holótipo macho. BRASIL, Rio Grande do Sul. "São Francisco de Paula / RS, Brasil / Pró-Mata 18.11.1996 / leg. Birgit Harter" ; "16078 H 354 / F. 85 12:30"; "Anthrenoides sp. C / [símbolo de macho] / B. Harter det. 1999" (DZUP). Parátipos. Santa Catarina, Seara (Nova Teutonia), X.1950, F. Plaumann leg., 1 macho (DZUP); IX.1951, L. E. Plaumann, [em Solanum], 1 fêmea (DZUP); 26.IX.1939, F. Plaumann leg., 1 macho e 1 fêmea (AMNH); 27.IX.1939, 1 macho e 1 fêmea (AMNH); 10.X.1939, 1 macho e 1 fêmea (AMNH). Rio Grande do Sul, S. Francisco de Paula (Pro-Mata), 6.XII.1995, Birgit Harter leg., 1 fêmea e 1 macho (DZUP); 18.XI.1996, 1 macho (DZUP); 21.XII.1997, 1 fêmea (DZUP); [Viamão], Parque Estadual de Itapuã, 27.IX.2003, Mardiore Pinheiro leg., 2 fêmeas (MCTP); 6.IX.2003, 1 macho (MCTP); 30.IX.2003, 1 macho (MCTP); Caçapava do Sul (Guaritas), 26.X.1991, C. Schlindwein leg. 1 fêmea (MCTP); Osório, 22.X.1991, I. Alves dos Santos leg., 3 fêmeas (MCTP); 10.XI.1993, 1 fêmea (MCTP) 
Comentários e variações. Na chave de Urban, 2005, o macho chega em A. paolae Urban, 2005, que tem tegumento micro-reticulado e fosco na cabeça e dorso do mesossoma. A fêmea chega em A. paranaensis Urban, 2005, que difere pela supraclipeal inteiramente micro-reticulada, sem área discal elevada e polida.

Foram observadas variações nos parátipos machos de $\mathrm{S}$. Francisco de Paula: um espécime com os três segmentos basais do metassoma castanho-avermelhados e, outro com áreas castanho-avermelhadas em todo o metassoma. Nas fêmeas foram constatadas áreas castanho-avermelhadas nos tergos e ausência de nódoa amarela na base das tíbias.

\section{Anthrenoides magaliae Urban, 2005}

Fig. 10

Anthrenoides magaliae Urban, 2005: 48.

A espécie foi descrita com base num exemplar macho de Viamão, Rio Grande do Sul.

A fêmea é descrita e seguir.

Diagnose. Fêmea. Máculas amarelas no clípeo, ao longo do comprimento e junto à sutura epistomal; máculas amarelas presentes ou não nas paroculares inferiores; clípeo e área supraclipeal polidos.

Comprimento aproximado 6,63; comprimento da asa anterior 4,52; largura da cabeça 2,03; altura da cabeça 1,64; comprimento do olho 1,25. Tegumento preto predominando, clípeo com mácula mediana amarela lembrando um "T", com o ramo horizontal acompanhando a sutura epistomal e mais estreito nos lados; asas tingidas de castanho, pterostigma amarelo-âmbar; esporões mesotibiais amarelo-âmbar; tergos com faixa marginal castanha larga; esternos com faixa marginal amarelada estreita.

Placa labral quase retangular, com cantos arredondados e algumas rúgulas transversais paralelas à articulação labroclipeal, carenas laterais ultrapassando um pouco a metade do comprimento da placa; clípeo polido e sem carena, com pontos grandes esparsos e pequena área basal micro-reticulada; supraclipeal polida com pontos nos flancos; fronte elevada em carena baixa com sulco mediano fino; fóveas faciais brilhantes, um pouco alargadas no meio, medindo cerca de 1/ 4 do comprimento do olho $(0,28: 1,25)$; mesoscuto microreticulado, com a pontuação densa na base e mais esparsa no disco; escutelo micro-reticulado com pontos maiores que os retículos e mais densos em volta; depressão basal do propódeo aproximadamente com o mesmo comprimento do metanoto, com rúgulas um pouco divergentes para os lados e o contorno posterior bem marcado; mesepisternos microreticulados; esporões mesotibiais com 3 dentes subapicais e numerosos dentículos para a base; tergos micro-reticulados e brilhantes, o basal com pontos finos esparsos, a partir do segundo com pontos maiores e mais densos, a faixa marginal brilhante e fracamente lineolada.

Pilosidade branca; denso-plumosa e curta no pronoto, tanto no colar como nos lobos, com pêlos longos de permeio; tíbias posteriores com cerdas brancas, um pouco enegrecidas junto à base; lados do terceiro e quarto tergos com franjas pouco conspícuas.

Material examinado. BRASIL, Rio Grande do Sul: Candiota (Chácara da HORTEC), um macho e 3 fêmeas (MCTP); um macho e uma fêmea (DZUP). Todos os espécimes estilopizados.

Variações. Foram examinadas duas fêmeas com as máculas amarelas do clípeo diferentes das descritas acima e também com manchas amarelas nas paroculares inferiores. Uma fêmea com o tegumento amarelo predominando no clípeo, não só junto à sutura epistomal mas até a ponta do clípeo, passando a um pouco acastanhado nos lados, reduzindo a área enegrecida aos cantos apicais do clípeo e, com estrias amarelas finas nas paroculares junto à sutura epistomal. A outra fêmea com nódoas amarelas paroculares junto ao clípeo e, a mácula clipeal junto à sutura epistomal com o contorno assimétrico e projetada medianamente até o disco. Uma das fêmeas com pontos mais densos no tergo basal. Também os machos mostraram variação, um macho com máculas amarelas paroculares quase quadradas, dos olhos quase até o topo da sutura subantenal externa e o clípeo com manchas amarelas irregulares no disco; o outro macho com as máculas paroculares em forma de gota, não chegando aos olhos, o clípeo com nódoas amarelas esparsas no disco e uma faixa amarela junto à sutura epistomal.

\section{Anthrenoides reticulatus Urban, 2005}

Anthrenoides reticulatus Urban, 2005: 55.

A espécie foi descrita com base em um exemplar macho. A fêmea é descrita a seguir.

Diagnose. Fêmea com o clípeo, área supraclipeal, mesoscuto e o escutelo micro-reticulados e quase foscos; área basal do propódeo com rúgulas bem marcadas divergentes para os lados e formando alvéolos; esporões mesotibiais quase tão longos como os basitarsos e com 4 a 6 dentes grossos.

Comprimento aproximado 9,21; comprimento da asa anterior 6,07; largura da cabeça 2,63; altura da cabeça 2,17; comprimento do olho 1,64. Tegumento enegrecido; face ventral das antenas amarelo-palha a partir da ponta do terceiro flagelômero; tégulas translúcidas castanhas; asas tingidas de amarelo-acastanhado, somente a $\mathrm{R}$ enegrecida, pterostigma amarelo-âmbar; esporão mesotibial castanho-escuro; tarsômeros distais amarelados; tergos e esternos com faixa marginal amarelada estreita.

Placa labral quase retangular com rúgulas divergentes e finas na metade basal, as carenas laterais nos $2 / 3$ distais; clípeo e supraclipeal micro-reticulados e quase foscos, o clípeo com pontos grandes e rasos também micro-reticulados, separados por espaços iguais aos pontos; na supraclipeal os pontos muito rasos e menores que os do clípeo; carena frontal muito fina e tão longa como a área supraclipeal; fóveas faciais longas, um pouco alargadas subapicalmente, menores que $1 / 3$ do 
comprimento do olho $(0,52: 1,64)$; mesoscuto e escutelo microreticulados e quase foscos, com pontos tão pequenos como os retículos, esparsos no mesoscuto e mais raros no escutelo; mesepisternos micro-reticulados; esporão mesotibial tão longo como o basitarso, com 4 a 6 dentes subapicais grossos e numerosos dentículos para a base; área basal do propódeo tão longa como o metanoto e com rúgulas bem marcadas divergentes para os lados e formando alvéolos. Tergos com a faixa marginal larga micro-reticulada, o primeiro com microreticulação brilhante e pontos muito finos e esparsos no disco, o segundo com pontuação fina porém densa.

Pilosidade branca predominando; no pronoto densoplumosa e alongada; as tíbias e basitarsos anteriores e medianos com cerdas castanhas, tíbias posteriores com as cerdas bicoloridas, castanhas na base e esbranquiçadas na metade distal; os basitarsos posteriores branco-pilosos; pêlos castanhos no quinto e sexto tergos; mesepisternos com cerdas finas dobradas em gancho na ponta.

Material examinado. BRASIL, Santa Catarina, Seara, Nova Teutônia, um macho; Rio Grande do Sul, São Francisco de Paula, duas fêmeas e um macho.

Comentários. Na chave de Urban (2005) a fêmea de $A$. reticulatus sai com A. paolae e A. ornatus. Anthrenoides paolae difere pelas fóveas faciais longas e rasíssimas, com os limites pouco perceptíveis, e A. ornatus difere pelo mesoscuto micro-reticulado e denso-pontuado, com os pontos separados por espaços variando de 1 a 2 diâmetros de ponto e pelas rúgulas muito esparsas ou ausentes na depressão basal do propódeo. Os machos de A. reticulatus examinados têm o escapo castanho-escuro, com área apical castanho-amarelada, sem a nódoa amarela apical, presente no holótipo.

Chave para as espécies de Anthrenoides do Rio Grande do Sul.

Incluindo como novos registros para o Rio Grande do Sul: A. palmeirae, coletada em Caçapava do Sul e Guaíba; A. paolae, em São Francisco de Paula e Viamão, no Parque Estadual de Itapuã; A. reticulatus, A. santiagoi e A. zanellai, coletadas em São Francisco Paula.

\section{Machos}

1. Tergos com faixa marginal opaca amarelada; glossa medindo aproximadamente 4 vezes o comprimento das gáleas. Clípeo protuberante, quando visto de perfil mais largo que as genas

A. admirabilis Urban, 2005

Tergos sem faixa marginal opaca amarelada; glossa não ultrapassando o dobro do comprimento das gáleas; clípeo pouco protuberante, mais estreito que as genas quando visto de perfil

2(1). Clípeo inteiramente enegrecido ou castanho, com ou sem máculas irregulares amarelas 3

Clípeo de cor predominante amarela ou esbranquiçada, com duas nódoas enegrecidas pequenas próximas das fóveas tentoriais
3(2). Paroculares inferiores com mácula amarela; clípeo castanho com áreas irregulares amarelas junto à sutura epistomal e no disco

A. magaliae Urban, 2005

Paroculares inferiores enegrecidas ou pretas; clípeo enegrecido ou com nódoa subapical amarela .......... 4

4(3). Genas com tubérculo ventral de formato piramidal; clípeo polido com projeções látero-apicais digitiformes .... A. ornatus Urban, 2005

Genas com angulosidade ventral obtusa, sem tubérculo; clípeo micro-reticulado com as projeções láteroapicais curtas em forma de lóbulos ou em arco rebaixado A. zanellai Urban, 2005

5(2). Placa labral amarela ou esbranquiçada, às vezes com nódoas irregulares castanhas ................................ 6

Placa labral preta ou castanha, sem nódoas amarelas . 12

6(5). Clípeo e máculas paroculares esbranquiçados ............. 7

Clípeo e máculas paroculares amarelos ......................... 8

7(6). Mesoscuto, escutelo e mesepisternos polidos; fronte com carena baixa entre os alvéolos; supraclipeal polida; primeiro palpômero labial mais longo que duas vezes a soma dos três palpômeros distais; ponta do oitavo esterno quase igual ao dobro do diâmetro do ocelo mediano ........................ A. antonii Urban, 2005

Mesoscuto, escutelo e mesepisternos micro-reticulados; fronte com carena fina até o ocelo mediano; supraclipeal micro-reticulada; primeiro palpômero labial pouco maior que a soma dos três palpômeros distais; ponta do oitavo esterno estreita, ultrapassando um pouco o diâmetro do ocelo mediano ....................................... A. francisci sp. nov.

8(6). Tergo basal com pontos finos muito esparsos; mesoscuto e escutelo micro-reticulados, quase foscos, com pontos finos esparsos; área supraclipeal microreticulada, fosca ou brilhante .................................. 9

Tergo basal com pontuação densa e grossa; mesoscuto e escutelo brilhantes com pontuação grossa, inteiramente polidos ou com áreas micro-reticuladas ao redor do mesoscuto; área supraclipeal polida ou em parte com micro-reticulação brilhante 10

9(8). Áreas paroculares com as máculas amarelas reduzidíssimas, pouco mais largas que o ocelo mediano porém mais curtas, distantes das órbitas e das suturas subantenais externas; área supraclipeal micro-reticulada e brilhante; genas estreitadas ventralmente, sem angulosidade; sexto esterno com as margens do recorte em "U" divergindo muito para a ponta, sem alargamento basal; sexto tergo com carena médio-apical curta .............. A. alineae sp. nov.

Áreas paroculares com as máculas amarelas grandes, mais longas junto às órbitas e alcançando o terço inferior das suturas subantenais externas; área supraclipeal micro-reticulada e fosca; genas largas ventralmente e com angulosidade; sexto esterno com 
as margens do recorte em "U" não divergindo para a ponta e com alargamento basal; sexto tergo sem carena médio-apical ......... A. reticulatus Urban, 2005

10(8). Sexto esterno com o recorte mediano quase em forma de "V", com a largura basal quase igualando o diâmetro do ocelo mediano, os bordos divergentes para a ponta; supraclipeal com pontuação grossa e densa A. micans Urban, 1995

Sexto esterno com o recorte mediano sem forma de "V", basalmente mais largo que uma vez e meia o diâmetro do ocelo mediano, os bordos retos ou divergindo para a ponta; supraclipeal sem pontuação no disco .. 11

11(10).Clípeo e supraclipeal polidos; máculas amarelas das paroculares quase quadrangulares; ponta da projeção mediana do oitavo esterno truncada com os cantos laterais arredondados ......... A. petuniae Urban, 2005

Clípeo e supraclipeal micro-reticulados; máculas amarelas das paroculares em forma de meia lua, o contorno quase reto junto às órbitas e o medial em arco; ponta da projeção mediana do oitavo esterno com pequenas angulosidades laterais ....... A. palmeirae Urban, 2005

12(5). Cabeça com protuberâncias gibosas nas áreas paroculares superiores, incluindo as fóveas faciais; área ocelar protuberante e com aspecto arredondado nos lados e posteriormente

Cabeça sem protuberâncias gibosas nas paroculares superiores; área ocelar com o tegumento um pouco elevado, não protuberante .. 14

13(12).Áreas subantenais parcialmente esbranquiçadas; clípeo e área supraclipeal polidos, o clípeo sem área microreticulada junto à sutura epistomal; escutelo polido

A. kelliae sp. nov.

Áreas subantenais inteiramente pretas; clípeo brilhante, polido em grande parte, com micro-reticulação nas proximidades do ramo transversal da sutura epistomal; supraclipeal micro-reticulada; escutelo micro-reticulado A. gibbosus sp. nov.

14(12).Máculas cefálicas esbranquiçadas; paroculares inferiores com as máculas muito curtas .... A. paulensis sp. nov.

Máculas cefálicas amarelas; paroculares inferiores com as máculas variáveis

15(14).Projeção mediana do oitavo esterno larga subapicalmente porém afinando muito para a ponta estreita e angulosa A. sulinus sp. nov.

Projeção mediana do oitavo esterno tão larga no meio como na ponta, o ápice truncado ou fracamente arredondado

16(15).Face micro-reticulada, quase fosca; mesoscuto e escutelo micro-reticulados, quase foscos; projeção mediana do oitavo esterno estreita, quase igual ao diâmetro do ocelo mediano A. paolae Urban, 2005

Face brilhante com áreas polidas e micro-reticuladas; mesoscuto e escutelo polidos ou com áreas micro- reticuladas brilhantes; projeção mediana do oitavo esterno tão larga como o dobro do diâmetro do ocelo mediano . 17

17(16).Clípeo e supra clipeal polidos, sem micro-reticulação; supraclipeal abaulada; sem carena frontal; tergo basal polido com pontos finos, sem micro-reticulação ..... A. meridionalis (Schrottky, 1906)

Clípeo e supraclipeal com área micro-reticulada brilhante nas proximidades da sutura epistomal; supraclipeal não abaulada, elevada para o meio em direção à área interalveolar; carena frontal curta; tergo basal com micro-reticulação brilhante e pontos finos esparsos A. elioi sp. nov.

\section{Fêmeas}

1. Tergos com faixa marginal amarelada larga e opaca; glossa extremamente longa, quase igualando o comprimento do corpo; clípeo protuberante, quando visto de perfil mais largo que as genas

A. admirabilis Urban, 2005

Tergos sem faixa marginal amarelada larga e opaca; glossa não como acima; clípeo pouco elevado ou protuberante, mais estreito que as genas quando visto de perfil

2(1). Pronoto com projeções látero-dorsais angulosas longas e voltadas para cima A. sidiae $\mathbf{s p . ~ n o v . ~}$

Pronoto sem projeções látero-dorsais angulosas voltadas para cima, o contorno liso ........................ 3

3(2). Clípeo inteiramente preto, sem nódoas amarelas ......... 4 Clípeo com máculas amarelas irregulares, junto à sutura epistomal ou ao longo do meio

A. magaliae Urban, 2005

4(3). Cabeça com protuberâncias gibosas nas áreas paroculares superiores, incluindo as fóveas faciais; área ocelar protuberante e com aspecto arredondado nos lados e posteriormente ............ A. kelliae sp. nov.

Cabeça sem protuberâncias gibosas nas paroculares superiores; área ocelar com o tegumento um pouco elevado, não protuberante

5

5(4). Mesepisternos polidos, podendo apresentar áreas microreticuladas esparsas e reduzidas; mesoscuto e escutelo polidos ................... A. antonii Urban, 2005

Mesepisternos micro-reticulados, foscos ou brilhantes; mesoscuto e escutelo variáveis

6

6(5). Fóveas faciais largas e quase retangulares na metade dorsal e muito estreitas ventralmente; esporão mesotibial com 4 a 5 dentes longos, o distal mais longo que o diâmetro do ocelo mediano e o dente subapical longo, um pouco menor que o ocelo ........

A. birgitae sp. nov.

Fóveas faciais estreitas e alongadas, ou alargadas medialmente ou subapicalmente; esporão mesotibial com o dente apical mais curto ou igual ao diâmetro do ocelo mediano, o dente subapical variável ......... 7 
7(6). Tergo basal denso-pontuado, os pontos até o limite com a faixa marginal, iguais ou maiores que os intervalos entre os mesmos; mesepisternos com pontos maiores que os retículos

Tergo basal geralmente com pontuação fina e esparsa, podendo apresentar pontuação mais densa dorsalmente porém com área sem pontos junto à faixa marginal; mesepisternos micro-reticulados com pontos finos esparsos

8(7). Clípeo polido porém com micro-reticulação brilhante na metade dorsal; placa labral com rúgulas finas divergentes para os lados; supraclipeal microreticulada nas proximidades da sutura epistomal e com pontos esparsos no disco; mesoscuto microreticulado A. palmeirae Urban, 2005

Clípeo polido, sem micro-reticulação; placa labral lisa, sem rúgulas divergentes para os lados; supraclipeal polida, com pontuação variável; mesoscuto polido

9(8). Fóveas faciais maiores que $1 / 3$ do comprimento dos olhos e mais largas que o escapo; primeiro palpômero labial mais longo que a soma dos 3 distais; supraclipeal com a área discal quase sem pontos ......

A. petuniae Urban, 2005

Fóveas faciais medindo quase $1 / 4$ do comprimento dos olhos e mais estreitas que o escapo, no máximo com pequena área larga como o escapo; primeiro palpômeros labial tão longo como a soma dos 3 distais; área supraclipeal com pontuação também no disco A. micans Urban, 1995

10(7).Clípeo, supraclipeal, mesoscuto e escutelo microreticulados, quase foscos; carena frontal fina e longa, até o ocelo mediano, irregular

... 11

Clípeo, supraclipeal, mesoscuto e escutelo com áreas polidas e micro-reticuladas, brilhantes; carena frontal presente ou ausente; quando presente não chegando ao ocelo mediano 12

11(10).Depressão basal do propódeo com alvéolos limitados por rúgulas alongadas; metade basal da placa labral com rúgulas divergentes para os lados

A. reticulatus Urban, 2005

Depressão basal do propódeo com rúgulas finas irregulares; placa labral com rúgulas basais esparsas A. paolae Urban, 2005

12(10).Primeiro palpômero labial tão longo como o dobro da soma dos três distais A. santiagoi Urban, 2005

Primeiro palpômero labial tão longo como a soma dos 3 distais ...... 13

13(12).Supraclipeal polida no disco, com ou sem área microreticulada junto à sutura epistomal ... 14
Supraclipeal micro-reticulada, brilhante ou quase fosca 16

14(13).Clípeo e supraclipeal sem área micro-reticulada junto à sutura epistomal; mesoscuto micro-reticulado com os pontos maiores que os retículos; tergo basal com área polida junto à faixa marginal; escutelo brilhante, com micro-reticulação fraca ....

A. meridionalis (Schrottky, 1906)

Clípeo e supraclipeal com área micro-reticulada junto à sutura epistomal; mesoscuto micro-reticulado com os pontos esparsos igualando os retículos; tergo basal sem área polida junto à faixa marginal; escutelo micro-reticulado, quase fosco 15

15(14).Tegumento micro-reticulado e brilhante entre os alvéolos antenais e os ocelos, os pontos brilhantes

A. elioi sp. nov.

Tegumento micro-reticulado e quase fosco entre os alvéolos antenais e os ocelos, com pontos rasos foscos pouco maiores que os retículos

A. sulinus $\mathbf{s p . ~ n o v . ~}$

16(13).Área basal do propódeo mais larga que o metanoto, inteiramente micro-reticulada ou com rúgulas muito rasas e esparsas, com o contorno posterior pouco marcado; placa labral mais longa que sua largura na ponta A. ornatus Urban, 2005

Área basal do propódeo mais estreita que o metanoto, com rúgulas formando alvéolos irregulares medianamente e com o contorno posterior um pouco elevado; placa labral mais curta que sua largura na ponta A. francisci sp. nov.

Na chave não constam as fêmeas de $A$. alineae sp. nov. , $A$. gibbosus sp. nov. , A. paulensis sp. nov. e A. zanellai; nem os machos de $A$. birgitae sp. nov., A. santiagoi e $A$. sidiae sp. nov.

Agradecimentos ao Dr. Elio Corseuil e Dra. Betina Blochtein do Museu de Ciências e Tecnologia da PUCRS pelo empréstimo do material para o estudo e pela doação de espécimes para a Coleção do DZUP; ao Projeto Taxon line - Rede Paranaense de Coleções Biológicas e à Aline Cristina Martins pelas fotos que ilustram o trabalho, ao Dr. Antonio J. C. Aguiar pela elaboração da prancha.

\section{REFERÊNCIAS}

Schrottky, C. 1906. Neue und wenig bekannte südamerikanische Bienen. Zeitschrift für systematische Hymenopterologie und Dipterologie VI: 305-316.

Urban, D. 1995. Espécies novas de Paracolletini e Panurginae do sul do Brasil e Argentina (Hymenoptera, Apoidea). Revista brasileira de Zoologia 12: 397-405.

Urban, D. 2005. Espécies novas de Anthrenoides Ducke (Hymenoptera, Andrenidae) do Brasil. Revista Brasileira de Entomologia 49: 36-62.

Urban, D. 2007. Espécies novas de Anthrenoides Ducke (Hymenoptera, Andreninae) do Sudeste do Brasil. Revista Brasileira de Entomologia 51: 23-34. 